University of Nebraska - Lincoln

DigitalCommons@University of Nebraska - Lincoln

2006

\title{
Social play in kakapo (Strigops habroptilus) with comparisons to kea (Nestor notabilis) and kaka (Nestor meridionalis)
}

Judy Diamond

University of Nebraska - Lincoln, jdiamond1@unl.edu

Daryl Eason

Department of Conservation, Nelson, New Zealand

Clio Reid

Victoria University of Wellington, NZ

Alan B. Bond

University of Nebraska - Lincoln, abond1@unl.edu

Follow this and additional works at: https://digitalcommons.unl.edu/bioscibehavior

Part of the Behavior and Ethology Commons

Diamond, Judy; Eason, Daryl; Reid, Clio; and Bond, Alan B., "Social play in kakapo (Strigops habroptilus) with comparisons to kea (Nestor notabilis) and kaka (Nestor meridionalis)" (2006). Papers in Behavior and Biological Sciences. 32.

https://digitalcommons.unl.edu/bioscibehavior/32

This Article is brought to you for free and open access by the Papers in the Biological Sciences at DigitalCommons@University of Nebraska - Lincoln. It has been accepted for inclusion in Papers in Behavior and Biological Sciences by an authorized administrator of DigitalCommons@University of Nebraska - Lincoln. 
Published in Behaviour 143 (2006), pp. 1397-1423. Copyright @ 2006 Koninklijke Brill NV, Leiden. Used by permission. http://www.brill.nl/beh

Accepted for publication September 29, 2006.

\title{
Social play in kakapo (Strigops habroptilus) with comparisons to kea (Nestor notabilis) and kaka (Nestor meridionalis)
}

\author{
Judy Diamond, ${ }^{1}$ Daryl Eason, ${ }^{2}$ Clio Reid,${ }^{3}$ and Alan B. Bond ${ }^{4}$
}

1 University of Nebraska State Museum, University of Nebraska-Lincoln, Lincoln, Nebraska, 68588 USA

2 Department of Conservation, Private Bag 5, Nelson, New Zealand 3 School of Biological Sciences, Victoria University of Wellington,

P.O. Box 600, Wellington, New Zealand

4 School of Biological Sciences, University of Nebraska-Lincoln, Lincoln, Nebraska, 68588 USA)

Corresponding author - J. Diamond, jdiamond1@unl.edu

\begin{abstract}
Summary
The play behavior of the critically endangered kakapo (Strigops habroptilus; Aves: Psittaciformes: Psittacidae) is here compared to that of its closest relatives, the kea (Nestor notabilis) and the kaka (Nestor meridionalis). Contrasting kakapos, which are relatively solitary, with the more social Nestor parrots provides an attractive test of the relative contributions of phylogeny and sociality to the evolution of play. Overlapping cluster analysis of play sequences using a hypergeometric similarity metric indicated that kakapo play is generally less complex, lacking the intensity, duration, structure, and reciprocity of play in the Nestor parrots. Kakapos have a later age of first reproduction than the comparison species, but they lack the well-developed social interactions between post-fledging young and adults that are characteristic of keas and kakas. Social play in parrots appears to be most readily predicted from their patterns of social development, emerging within a constellation of behaviors associated with independent young that remain in the vicinity of adult groups.
\end{abstract}

Keywords: kakapo, social play, juvenile sociality, cluster analysis

\section{Introduction}

Social play is generally uncommon in birds. It has been unambiguously described in only three of the 22 avian orders [Psittaciformes, 
Passeriformes (Corvidae and Timaliidae) and Bucerotiformes; Ortega \& Bekoff, 1987; Diamond \& Bond, 2003]. Among the parrots, corvids, and babblers, however, there are species that display such extensive and conspicuous social play as to be on a par with many mammals. The best documented examples are ravens (Corvus corax; Wilmore, 1977; Heinrich \& Smolker, 1998), Australian magpies (Gymnorhina tibicen; Pellis, 1981a, b, 1982), Arabian babblers (Turdoides squamiceps; Pozis-Francois et al., 2004), keas (Nestor notabilis; Potts, 1969; Keller, 1975; Diamond \& Bond, 1999), and kakas (Nestor meridionalis; Diamond \& Bond, 2004). The irregular distribution of social play across taxonomic groupings suggests that the behavior may reflect an evolutionary response to particular ontogenetic and ecological circumstances. In the model proposed by Diamond \& Bond (2003), birds would be predicted to engage in social play if (1) they belong to a relatively large-brained, altricial order, (2) they live in complex, stable social groups, and (3) they mature slowly and maintain an extended post-fledging association between juveniles and adults (Ortega \& Bekoff, 1987; Skutch, 1987; Collar, 1997; Heinrich \& Smolker, 1998; Power, 2000; Diamond \& Bond, 2003).

The most productive approach to refining and testing models of behavioral evolution is the comparative method, which contrasts sets of closely related species that differ from one another in some focal aspect of their ecology or life history (Felsenstein, 1985; Kamil, 1988; Harvey \& Pagel, 1991). Explicit observations or experimental tests are conducted to determine whether differences in the occurrence of the behavior across species are predicted by the contrasts in their life history. The use of phylogenetically related species provides an effective control for the influence of common descent. If the behavior pattern is not an evolutionary consequence or correlate of the contrasting features, the null hypothesis would predict it to be displayed in a similar form in all members of the group. When such comparisons are performed iteratively on clusters of related taxa, this method can provide compelling evidence for evolutionary causation, as has been shown in comparative studies of spatial memory in food-caching birds (reviewed in Shettleworth, 1998) and transitive inference in social corvids (Bond et al., 2003; Paz-y-Miño et al., 2004).

The only systematic comparison of social play between closely related species of birds has been the work on keas and kakas by Diamond \& Bond (2004). They found that episodes of social play in keas were longer in duration than those of kakas, more diverse, and less tightly structured. Kea play was also more broadly distributed among 
age groups and far more likely to involve joint manipulation of play objects (Diamond \& Bond, 2004). These contrasts in play behavior were generally consistent with differences between the species in the course of their development and their degree of sociality (Diamond \& Bond, 2003). Keas take longer to reach sexual maturity than kakas and characteristically live in more complex social groupings that include extensive post-fledging associations between juveniles and adults. However, the life history differences are mainly matters of degree. Both keas and kakas are relatively social birds, with similar ages of first reproduction and overlapping ecological niches. A more definitive test of the predictive model would compare keas and kakas to a closely related species that provides a stronger contrast in life history and social organization.

The most appropriate comparison species, by this argument, is the kakapo, Strigops habroptilus. Kakapos are large, flightless, nocturnal parrots endemic to New Zealand. They are one of the world's rarest birds; the entire known population of 86 individuals lives on predator-free, offshore island refuges (Eason \& Moorhouse, 2006). Based on recent evidence from molecular systematics, keas and kakas are the kakapo's closest relatives (Sainsbury et al., 2004; de Kloet \& de Kloet, 2005; Forshaw, 2006). In spite of their taxonomic affinity, however, adult kakapos are far less social than either keas or kakas, and their relative brain size is significantly smaller (Iwaniuk et al., 2004). Unlike the monogamous, biparental breeding systems characteristic of most other parrots, kakapos are a lekking species (Merton et al., 1984; Collar, 1997; Juniper \& Parr, 1998; Higgins, 1999). During the breeding season, adult males aggregate at traditional lek sites, where they maintain and defend a complex system of excavated bowls. The bowls serve as resonators for the booming vocal display that is used to attract females (Merton et al., 1984). Aside from reproduction, adult kakapos are generally considered to be solitary, and the males, in particular, are mutually aggressive (Higgins, 1999).

Kakapos also contrast with keas and kakas in their ontogeny and juvenile dispersal. With the largest body mass of any parrot, kakapos are one of the slowest developing species in the order, reaching sexual maturity at nearly twice the age typical for keas (Merton et al., 1984; Juniper \& Parr, 1998). Breeding occurs infrequently at up to 6year intervals, triggered by the availability of high quality food (Elliott et al., 2001; Cockrem, 2002). After mating, the female returns to her home range and constructs a nest site in a natural cavity where 
she lays from 1 to (rarely) 4 eggs. Incubation lasts for about 30 days. The chicks are cared for solely by their mother and fledge at about 10 weeks of age (Powlesland et al., 1992; Higgins, 1999; Farrimond, 2003; Eason et al., 2006). Farrimond (2003) studied the dispersal of 24 juvenile kakapos produced in 2002, the most successful breeding season on record. She suggests that kakapos have an extended period of post-fledging dependence. For three to four months, the fledglings remain within about $100 \mathrm{~m}$ of the nest site and may continue to solicit food from the mother. For another four to five months, they commonly remain within the mother's home range or roost near her during the day.

At least in terms of spatial distribution, therefore, the post-fledging association between female kakapos and their offspring appears to be comparable in duration to that observed in keas and kakas. Aside from the interactions of adults at lek sites, however, little is known of the social behavior of kakapos in the field. This is scarcely surprising, given that they are "rare, nocturnal, cryptically colored, solitary, shy, (and) inhabit dense cover in remote and inhospitable country" (Higgins, 1999, p. 639). There are anecdotes of apparently playful interactions between captive kakapos and their human keepers (e.g., Butler, 1989; Climo \& Ballance, 1997), but social play between juvenile birds has not been systematically recorded. This study provides the first quantitative description of social play in kakapos and the first detailed comparison of kakapo play to that of other, related species.

\section{Methods}

As part of kakapo management since 1997, nestlings that are ill, injured, or significantly underweight are removed from the nest and hand-reared in captivity. Chicks are first brought to a temporary brooding facility in a portable incubator. Once their condition has stabilized, they are transported by air to the main hand rearing facility at Nelson on the South Island. Members of the New Zealand Department of Conservation's National Kakapo Team videotaped the social interactions of a group of four hand-reared kakapo fledglings at this facility. These were the only offspring of the species to survive the 2005 breeding season (Eason et al., 2006). All were hatched from nests on Codfish Island (Whenua Hou), where most of the breeding population of kakapos is maintained. 
Of the four birds, two females and one male hatched between March 18 and 19, 2005, and one female hatched on April 6, 2005. The two older females, Poura and Yasmine, were siblings and were housed together from hatching. The younger female, Pounamu, was introduced to Poura and Yasmine on May 16, when she was 39 days of age. The male, Kumi, was introduced to the three females on May 25, when he was 65 days of age. Their interactions were videotaped on June 5-19, 2005, when the older fledglings were between 79 and 93 days of age and the younger one (Pounamu) was between 61 and 75 . At the time of recording, the three older birds appeared to be roughly equivalent in their development. Pounamu, however, had been removed from the nest at a far younger age than the others and was clearly less mature, still retaining evidence of her natal down. All four birds were returned to an outdoor enclosure on Codfish Island on June 22, 2005 and have since been released into the wild.

During the course of this study, the four chicks were housed in an enclosure approximately $2.4 \mathrm{~m}^{2}$ containing numerous beech (Nothofagus) branches. Observers visited the birds nearly every day between 06:00 and 23:00 and videotaped them opportunistically whenever social interactions were evident, resulting in over three hours of recordings. Recording sessions were usually sustained as long as the chicks continued to interact, terminating only when they settled down (usually to sleep) or when competing maintenance duties intervened.

Criteria for identification of social play are well established in the literature (reviewed in Fagen, 1981; Bekoff \& Byers, 1981; Power, 2000; Burghardt, 2005; see also Bekoff, 1976, 1984; Barber, 1991; Bekoff \& Allen, 1998; Spinka et al., 2001). Social play in birds shares many characteristics with that of mammals. It generally incorporates actions from a variety of contexts into labile temporal sequences in interactions between two or more individuals. Because play lacks consummatory behaviors (Lorenz, 1956), furthermore, interactions are commonly repeated, with the partners alternating roles until they are distracted by other stimuli. Social play most often occurs between juveniles (Power, 2000), but different kinds of social play may have different players and developmental time courses (Bekoff, 1974; Fagen, 1981; Simmons \& Mendelsohn, 1993). In birds, social play generally consists of play chasing, play fighting, play invitations, and social object play (Diamond \& Bond, 2003, 2004). 
A bout of social play was defined as beginning with the first recognizable play behavior and terminating when the individuals separated, either when there was a pause in the action long enough for the birds to begin to engage in other behaviors or as a result of one of the play partners' moving away from the other. The presence or absence of each action pattern in each bout was noted on check-sheets. Presence/absence encoding has commonly been used in studies of primate behavior (e.g., Kraemer, 1979; Singh, 1989), producing acceptable measures of relative incidence (Tyler, 1979; Rhine \& Linville, 1980; Zinner et al., 1997). It is particularly well suited to cluster analysis, yielding robust and readily interpretable data structures (e.g., Cassini \& Vila, 1990; Diamond \& Bond, 1999, 2004). Categorization of bout contents was arrived at by consensus of three observers (JD, CR, $\& A B)$. A total of 3 hours and 35 minutes of videotape were included in the analysis, yielding 114 identifiable social play interactions.

Our observations of play in kakapos were contrasted to a data base of records of kea and kaka play that had previously been accumulated from field observations (Diamond \& Bond, 2004). The kea data were collected between 1988 and 1991 at the Halpin Creek refuse dump, adjacent to Arthur's Pass National Park (Diamond \& Bond, 1991, 1999). Additional incidents of kea play were observed in 2000 at a refuse dump near Fox Glacier in Westland National Park. Observations of kaka play were collected during 2001 and 2003 from an aggregation at a sugar-water feeder adjacent to a private residence in the village of Oban on Stewart Island. The data base consisted of 21 instances of play in keas and 41 instances in kakas; in both species, a single play instance often encompassed multiple bouts. Instances of play in both species were recorded on video, as time-event sequences on a computer-based event recorder, or in written check-lists.

We tested for species differences in the proportion of bouts in which each action pattern was observed and in the average duration of play interactions. To compare the structure of play interactions in the three species, the array of presence/absence data (behaviors $x$ bouts) for each species was converted to a similarity matrix using the cumulative hypergeometric method (Li \& Dubes, 1984, 1989). In this approach, a similarity index between pairs of behavioral variables is estimated by computing the probability of obtaining no more than the observed number of matches, if the entries in the respective columns of the sample matrix were randomly permuted. The hypergeometric similarity index is essentially the statistical significance of a binary correlation between two action patterns. We implemented Li \& 
Dubes' technique using Wu's (1993) prime factorization algorithm to obtain fast, accurate values for the hypergeometric distribution and a sieve algorithm from Luo (1989) to compute vectors of primes.

In earlier analyses (Diamond \& Bond, 2004), the event similarity matrices were converted to cluster structures using oblique principal component cluster analysis and displayed as hierarchical trees. Hierarchical clustering has the disadvantage, however, that each variable is assumed to occur in only one of the resultant groupings. In consequence, each action pattern adheres only to the most common cluster of which it is a component. This is not necessarily a realistic assumption in the analysis of social play, in which a single action pattern may occur in multiple contexts. Play action patterns are generally clustered in their occurrence, but the clusters overlap to some degree, with a single action pattern sometimes contributing to more than one cluster. Similar statistical problems in psychology have been addressed with overlapping or additive clustering techniques (Shepard \& Arabie, 1979; Arabie \& Carroll, 1980, 1989). The algorithms employed in these studies, however, are computationally intensive and appear to work with only very well-behaved data sets. In contrast, hypergeometric similarities, because they directly express the significance of the association between behavioral variables, can be robustly converted to an overlapping cluster structure by simple thresholding. In this approach, the relationships in the similarity matrix are displayed using multidimensional scaling (Morgan et al., 1976; Arabie et al., 1981; Arabie \& Carroll, 1989). Pairs of action patterns with statistically significant similarity values are linked with line segments, and when the segments produce a closed polygon, the polygon is shaded in, and the corresponding action patterns are considered to form a meaningful cluster.

\section{Results}

\section{Incidence}

Social play in kakapos generally took place between pairs of birds. Only $10 \%$ of our sample consisted of interactions among three or four individuals. This was comparable to the incidence of multiple-player bouts in keas $(14 \%)$; in kakas, simultaneous play participation by more than two individuals was not observed. The four fledgling kakapos were not equivalently social. One or both of the two sibling females, Poura and Yasmine, participated in $65 \%$ of the 103 dyadic play 
interactions, while the other two birds, Pounamu and Kumi, were involved in only $35 \%$. The probability of social interaction across individuals was, thus, significantly different from an expectation of equality $\left(x_{3}^{2}=23, p<0.001\right)$, but there were no indications of consistent play partners: The relative frequencies of the six possible dyads were consonant with random association $\left(X_{5}^{2}=10.4, p>0.06\right)$. Thus, the sibling females played more frequently than the other two chicks, but not necessarily with each other.

Kakapo play occurred in relatively brief bouts of interaction, typically 10-20 s in duration. The median duration of 114 bouts of kakapo play was $12 \mathrm{~s}$ (interquartile range $=16$ ), while that of 55 bouts of kaka play was $27 \mathrm{~s}$ (interquartile range $=48.5$ ) and of 28 bouts of kea play was $48 \mathrm{~s}$ (interquartile range $=60$ ). Play bouts in both keas and kakas were significantly longer than those in kakapos $\left(w^{+} \geq 3207, z \geq 5.61\right.$, $p<0.001)$.

\section{Component action patterns}

During play interactions, kakapos displayed a total of ten distinctive action patterns (Table 1), although two of them (Hang and Manipulate Object) were observed so infrequently that they could not be included in the cluster analysis. Six of the ten patterns were analogous to play action patterns shown by keas or kakas; two other patterns displayed in the Nestor parrots were never observed in kakapos (Head Cock and Toss). One action pattern, Chin Over, was frequently performed by fledgling kakapos, but has never been recorded in either keas or kakas.

Play invitations generally take similar forms in keas and kakas. These species both solicit play by approaching their play partners in a distinctive series of small, oblique hops, often while cocking their heads to one side, and they both use rolling over on their backs to entice a play partner to continue or resume social play. Such ritualized play invitations were not observed in kakapos (Table 2): Kakapos did not cock their heads in social interactions, and they showed clear play hops in only five out of 114 interactions. When they did roll over on their backs, the behavior did not appear to serve a communicatory function. Rolling over was performed by kakapos that were not actively engaged in social interaction, and the other birds showed no evident response to the posture.

One of the most characteristic features of kea play consists of extended sequences in which the two birds stand facing each other 
Table 1. Comparative ethogram of play in keas, kakas, and kakapos.

\begin{tabular}{|c|c|c|c|}
\hline Behaviour & Occurrence in kakapo & Comparison to kaka & Comparison to kea \\
\hline Bite & $\begin{array}{l}\text { Kakapos use their } \\
\text { bill to nuzzle against } \\
\text { and occasionally } \\
\text { gently grasp another } \\
\text { bird's feathers, bill, } \\
\text { or feet. The partner } \\
\text { does not react to this } \\
\text { as if pain were in- } \\
\text { flicted. Painful bites } \\
\text { were not observed } \\
\text { in kakapos. }\end{array}$ & $\begin{array}{l}\text { Kakas use their bill to } \\
\text { surround another's } \\
\text { body part and gently } \\
\text { and briefly hold it. } \\
\text { The partner does not } \\
\text { react to this as if pain } \\
\text { were inflicted. Painful } \\
\text { bites were an infre- } \\
\text { quent component of } \\
\text { play in kakas. }\end{array}$ & $\begin{array}{l}\text { Bites are a common } \\
\text { component of play } \\
\text { in keas. During play, } \\
\text { keas repeatedly grasp } \\
\text { the tail, feet, or legs } \\
\text { of their partner with } \\
\text { their bills, and the } \\
\text { partner reacts by vo- } \\
\text { calizing or by jerking } \\
\text { away suggesting that } \\
\text { some pain may have } \\
\text { been inflicted (Keller, } \\
\text { 1976; Diamond \& } \\
\text { Bond, 1999). }\end{array}$ \\
\hline
\end{tabular}

Head Cock Not observed in kakapos.
Kakas frequently turn their head on one side while looking at or approaching another in play. Often the head turning movement is extreme, resulting in the head being nearly upside down. This behavior is conspicuous at the onset of play interactions and often leads to rolling over.
Keas sometimes initiate play by approaching another while head cocking, but it is not as conspicuous as in kakas.

$\begin{array}{ll}\text { Wing Flap } & \begin{array}{l}\text { Kakapos may } \\ \text { briefly flap their } \\ \text { outstretched wings } \\ \text { while approaching } \\ \text { another individual. }\end{array}\end{array}$

Kakas rapidly flap their outstretched wings while hanging upside-down from a tree branch. This also occurs during play on the ground in kakas that are attempting to maintain their position on top of a supine partner.
Keas that are trying to keep their balance on a supine partner use wing flaps, but they also engage in mutual jumping and wing flapping as a separate, distinctive component of social play. 
Table 1 (continued). Comparative ethogram of play in keas, kakas, and kakapos.

\begin{tabular}{|c|c|c|c|}
\hline Behaviour & Occurrence in kakapo & Comparison to kaka & Comparison to kea \\
\hline Foot Push & $\begin{array}{l}\text { Kakapos sometimes } \\
\text { push a play partner } \\
\text { with a foot as an iso- } \\
\text { lated action or while } \\
\text { engaged in bill lock. } \\
\text { Foot pushes are not } \\
\text { generally recipro- } \\
\text { cated by the other } \\
\text { individual. }\end{array}$ & $\begin{array}{l}\text { Mutual foot pushing } \\
\text { is one of the most } \\
\text { common features of } \\
\text { kaka social play. It oc- } \\
\text { curs while one bird is } \\
\text { standing on another's } \\
\text { stomach, while it is } \\
\text { lying on its side next } \\
\text { to its partner, or while } \\
\text { it is hanging upside } \\
\text { down next to another. } \\
\text { Kakas sometimes } \\
\text { grasp a partner with } \\
\text { one foot to attempt to } \\
\text { draw them back into } \\
\text { a play interaction. }\end{array}$ & $\begin{array}{l}\text { Keas engage in vigor- } \\
\text { ous mutual foot push- } \\
\text { ing, most commonly } \\
\text { from a standing posi- } \\
\text { tion. Keas sometimes } \\
\text { fly over another bird } \\
\text { and hit them with } \\
\text { their feet. }\end{array}$ \\
\hline Hang & $\begin{array}{l}\text { Kakapo fledglings } \\
\text { were rarely ob- } \\
\text { served to hang by } \\
\text { the their bill from } \\
\text { branches in the en- } \\
\text { closure, but they did } \\
\text { not engage in social } \\
\text { interactions while } \\
\text { hanging. }\end{array}$ & $\begin{array}{l}\text { Kakas frequently } \\
\text { hang from a branch } \\
\text { by the bill or by one } \\
\text { or both feet with head } \\
\text { and body upside- } \\
\text { down, sometimes } \\
\text { flapping the wings. It } \\
\text { occurs during social } \\
\text { play, during solitary } \\
\text { displays of hanging } \\
\text { when they demol- } \\
\text { ish vegetation and } \\
\text { vocalize loudly, and } \\
\text { also as a component } \\
\text { of locomotion during } \\
\text { foraging. }\end{array}$ & $\begin{array}{l}\text { Keas sometimes hang } \\
\text { during social play } \\
\text { and as a component } \\
\text { of general locomotion } \\
\text { during foraging. Keas } \\
\text { less commonly hang } \\
\text { by one foot in arbo- } \\
\text { real play and will bite } \\
\text { or fly into a bird that } \\
\text { is hanging, attempt- } \\
\text { ing to knock him off } \\
\text { (Diamond \& Bond, } \\
\text { 1999). }\end{array}$ \\
\hline
\end{tabular}

\begin{tabular}{|c|c|c|}
\hline Hop & $\begin{array}{l}\text { Kakapos sometimes } \\
\text { approach another } \\
\text { bird while hopping, } \\
\text { using both feet } \\
\text { simultaneously in } \\
\text { short bouncy move- } \\
\text { ments, often ac- } \\
\text { companied by wing } \\
\text { flapping. }\end{array}$ & $\begin{array}{l}\text { Kakas hop by moving } \\
\text { to or from another } \\
\text { bird along the ground } \\
\text { using both feet simul- } \\
\text { taneously in short } \\
\text { bouncy movements. } \\
\text { Such oblique, bouncy } \\
\text { hops are often a } \\
\text { means of soliciting of } \\
\text { maintaining play. }\end{array}$ \\
\hline
\end{tabular}

Keas often hop toward other birds during play, but less often as a prelude to it. Hopping often accompanies vertical tossing of objects in play interactions. 
Table 1 (continued). Comparative ethogram of play in keas, kakas, and kakapos.

\begin{tabular}{|c|c|c|c|}
\hline Behaviour & Occurrence in kakapo & Comparison to kaka & Comparison to kea \\
\hline Jump & $\begin{array}{l}\text { Kakapo jump to- } \\
\text { wards another indi- } \\
\text { vidual, sometimes } \\
\text { accompanied by } \\
\text { wing flap. Kakapo } \\
\text { have been observed } \\
\text { to hop up to and } \\
\text { jump onto another } \\
\text { slumbering chick's } \\
\text { back and the slum- } \\
\text { bering chick nor- } \\
\text { mally wakes with } \\
\text { alarm and a loud } \\
\text { call (Eason, personal } \\
\text { communication). }\end{array}$ & $\begin{array}{l}\text { Kakas repeatedly } \\
\text { jump on the stomach } \\
\text { of a supine partner as } \\
\text { part of play. They also } \\
\text { jump over another } \\
\text { bird, and sometimes } \\
\text { jump in the air next to } \\
\text { a play partner. Kakas } \\
\text { jump and wing flap } \\
\text { in play, but we did } \\
\text { not observe them to } \\
\text { do this in unison or } \\
\text { repeatedly. }\end{array}$ & $\begin{array}{l}\text { Keas often jump on } \\
\text { the stomach on a su- } \\
\text { pine partner as part } \\
\text { of play (Potts, 1969). } \\
\text { They also jump over } \\
\text { another bird, and } \\
\text { sometimes in the air } \\
\text { next to a play partner. } \\
\text { Keas engage in re- } \\
\text { peated mutual jump- } \\
\text { ing and wing flapping } \\
\text { as a major component } \\
\text { of social play. }\end{array}$ \\
\hline Bill Lock & $\begin{array}{l}\text { Kakapos gently } \\
\text { touch bills, nuzzling } \\
\text { the bills together } \\
\text { rather than twisting } \\
\text { them. Bill touching } \\
\text { occurred frequently } \\
\text { with chin over. }\end{array}$ & $\begin{array}{l}\text { Kakas sometimes } \\
\text { touch their bills to } \\
\text { each other very brief- } \\
\text { ly in play. Locking } \\
\text { and twisting bills is } \\
\text { very seldom observed } \\
\text { in kakas. }\end{array}$ & $\begin{array}{l}\text { A kea will grasp } \\
\text { another's maxilla in } \\
\text { its bill, twisting and } \\
\text { pushing, using its } \\
\text { own body weight } \\
\text { for leverage (Keller, } \\
\text { 1975). This behavior is } \\
\text { a common feature of } \\
\text { kea play. }\end{array}$ \\
\hline $\begin{array}{l}\text { Manipulate } \\
\text { Object }\end{array}$ & $\begin{array}{l}\text { Kakapos grab } \\
\text { leaves and branches } \\
\text { in their bills, twist- } \\
\text { ing or pulling at } \\
\text { them. Social ma- } \\
\text { nipulation of objects } \\
\text { was not observed. }\end{array}$ & $\begin{array}{l}\text { Kakas sometimes } \\
\text { grasp tree fronds } \\
\text { or branches in their } \\
\text { bill while playing in } \\
\text { trees or tree ferns, but } \\
\text { they do not appear to } \\
\text { manipulate these or } \\
\text { other objects in the } \\
\text { course of their play. }\end{array}$ & $\begin{array}{l}\text { Keas often pick up } \\
\text { small rocks or other } \\
\text { small objects on the } \\
\text { ground in the course } \\
\text { of a play interaction. } \\
\text { They will also try to } \\
\text { grasp an object with } \\
\text { their bill that is al- } \\
\text { ready being held by } \\
\text { another kea, resulting } \\
\text { in a tug-of-war or a } \\
\text { chase to retrieve the } \\
\text { object. Object play is a } \\
\text { very common compo- } \\
\text { nent of kea play. }\end{array}$ \\
\hline
\end{tabular}


Table 1 (continued). Comparative ethogram of play in keas, kakas, and kakapos.

\begin{tabular}{cll}
\hline Behaviour & Occurrence in kakapo & Comparison to kaka \\
\hline Roll Over & $\begin{array}{l}\text { Kakapos were } \\
\text { observed to roll } \\
\text { over on their } \\
\text { backs with their } \\
\text { feet in the air, but } \\
\text { they were not ap- } \\
\text { proached by oth- } \\
\text { ers while in this } \\
\text { position. }\end{array}$ & $\begin{array}{l}\text { In play, a kaka rolls its } \\
\text { entire body over and lies } \\
\text { on its back while gently } \\
\text { moving its feet. The roll } \\
\text { may begin with turning } \\
\text { the head or wing under. }\end{array}$ \\
$\begin{array}{ll}\text { When it begins with the } \\
\text { produce action may }\end{array}$ \\
& $\begin{array}{l}\text { or sideways roll. When } \\
\text { it begins with the wing, } \\
\text { the action ends with the } \\
\text { bird lying on its back. }\end{array}$ \\
& Kakas roll over on their \\
backs and wave their \\
feet in the air as a major \\
component of play inter- \\
actions. In kakas, rolling \\
over often follows from \\
a head cock.
\end{tabular}

Comparison to kea

Keas perform a virtually identical action pattern to kakas, rolling over on their backs and waving their feet in the air, as a component of play interactions.

\begin{tabular}{lll}
\hline Toss & $\begin{array}{l}\text { Tossing was not } \\
\text { observed in kaka- } \\
\text { pos. }\end{array}$ & $\begin{array}{l}\text { Tossing was not ob- } \\
\text { served in kakas during } \\
\text { play or in any other } \\
\text { context. }\end{array}$
\end{tabular}

In play, a kea typically holds an object in its bill and then jerks the head vertically, releasing the object in the air, sometime in the direction of the play partner. The bird may also hop or flap its wings just before releasing the object (Potts, 1969). It may persist in tossing the object for several minutes. Tossing occurs in keas as a component of solitary play, social play between juveniles, and courtship play between adults (Diamond \& Bond, 1999).

Chin Over Kakapos place their chin over the back or neck of another individual, while standing next to them.
Chin over was not observed in kakas.
Chin over was not observed in keas. 
Table 2. Percentage of play bouts including one or more occurrences of the specified action pattern, based on samples of 114 bouts from kakapos, 55 from kakas and 28 from keas.

\begin{tabular}{lcll}
\hline Behavior & Kakapo & Kea & Kaka \\
\hline Bite & 58.77 & $60.71 \mathrm{NS}$ & $67.27 \mathrm{NS}$ \\
Head Cock & - & 10.71 & 61.82 \\
Wing Flap & 43.86 & $82.14^{* *}$ & $87.27^{* *}$ \\
Foot Push & 16.67 & $71.43^{* *}$ & $69.09^{* *}$ \\
Hang & 0.88 & $3.57 \mathrm{NS}$ & $36.36^{* *}$ \\
Hop & 4.39 & $53.57^{* *}$ & $56.36^{* *}$ \\
Jump & 15.79 & $82.14^{* *}$ & $56.36^{* *}$ \\
Bill Lock & 47.37 & $35.71 \mathrm{NS}$ & $1.82^{* *}$ \\
Manipulate & 0.88 & $21.43^{* *}$ & - \\
Roll Over & 4.39 & $39.29^{* *}$ & $69.09 * *$ \\
Toss & - & 10.71 & - \\
Chin Over & 50.88 & - & - \\
\hline
\end{tabular}

Dashes indicate that the behavior was not observed in the given species. Significance of differences between kakapos and each of the other two species were tested with Fisher's exact tests: ${ }^{*}=p<0.01 ;{ }^{*}=p<0.05 ; \mathrm{NS}=$ not significant.

breast to breast and simultaneously jump up and down while vigorously flapping and striking each other with their wings. In kakapos, jumping and wing-flapping appeared to be mainly an indication of the excited state of an individual fledgling, and it was often part of a sequence that included suddenly running around the enclosure, jumping on things, and flapping their wings. Kakapo chicks have been observed to run up to and jump onto a slumbering chick's back, causing the chick to wake up and produce loud vocalizations (Eason, personal communication). Unlike keas and kakas, the wing flaps and jumps of kakapos did not appear to be attempts to spar with play partners, and they did not lead to other social play behaviors. Overall, jumping, hopping, and wing-flapping were significantly less common in kakapos than in either of the Nestor parrots (Table 2).

The most common action patterns in kakapo play were components of mild play fighting. Kakapos, like most other parrots, bite each other's feathers and feet, fence with their bills, and push at their play partners with their feet. These behaviors were relatively frequent in all three species (Table 2), but there were still species differences. Kakapo play fighting was much gentler and less strenuous than that of either of the Nestor parrots. Kakapo bites were so gentle as to be virtually unnoticed by the recipient bird, their bill con- 
tact consisted mainly of bouts of mutual touching and nibbling, and foot-pushing was much less frequent in kakapos than in the other two species. In contrast, keas often bite each other strongly during play, grabbing their partner by the tail, feet, or legs with their bills and sometimes even dragging the partner across the ground (Diamond \& Bond, 1999), and bill-to-bill contact in keas resembles nothing so much as an avian version of arm-wrestling. Kakas are less likely to lock bills, but they engage in prolonged wrestling matches with their feet, either with one partner on its back on the ground or with both of them hanging by one foot from a branch. We observed nothing in kakapos comparable to the vigorous, reciprocal wrestling of keas and kakas.

As part of play fighting, kakapos exhibited a unique action pattern, Chin Over, that has not previously been described in the literature. In this behavior, one of the birds places its chin over its partner's neck, locking the birds together like a pair of overlapping fingers. The linked posture is generally held for a period of several seconds and then released. This behavior has not been recorded from keas or kakas, but it was one of the most frequent components of social interactions in fledgling kakapos. On a number of occasions, birds were seen to shift their position so as to avoid an attempted chin over by their partner, and we recorded several interactions in which the partners stood facing each other, craning their necks in an evident attempt to place their chin over the other bird. Such competition in the performance of the display suggests that it could be an expression of relative social dominance. However, the incidence matrix for Chin Over showed evidence of asymmetry only between one pair of birds (the sibling females), which seems inconsistent with a dominance display.

Like most parrots, kakapos chew on and manipulate anything in their environment, including leaves, branches, food items, and inedible objects, such as plastic nest boxes and food bowls. There is little indication, however, of the use of objects as adjuncts to social play. In the one instance of social object manipulation in our data set, a pair of kakapos engaged in an extended interval of parallel, but non-interactive, chewing and rolling over on a rubber boot that was left in their pen. This activity eventually segued into a short play interaction, at which time the object manipulation ceased. Of the three species, only keas actively manipulate objects in the context of social play, tossing them up and playing tug-of-war or keep-away with them (Diamond \& Bond, 1999, 2004). 
Compared to kea and kaka interactions, kakapo play appeared to have much more limited reciprocity. Typically, one bird would initiate an interaction by simply approaching another individual and biting the recipient's foot or placing its chin over the other bird's neck. Recipients commonly responded by tolerating the initiator of the interaction without engaging in other play behaviors or by slowly moving away. Some reciprocal biting and foot-pushing occurred within single play bouts, but once the recipient moved away, there was little indication of an effort by either partner to return and reinitiate the interaction. This limited social dynamic was in striking contrast to play in keas and kakas, which typically persists over multiple successive bouts. Play partners in Nestor parrots often actively resist termination of a play bout. Kakas, for example, will cling to their play partner with one foot, apparently in an effort to draw him back into further interactions (Diamond \& Bond, 2004).

\section{Interaction structure}

The cluster structure produced from the observations on all four kakapos showed three significant linkages and three linkage trends, but no coherent clusters of three of more action patterns. We conducted a jackknife analysis (Gray \& Schucany, 1972) to evaluate the relative contributions of the four individual kakapos to the cluster structure, eliminating all interactions that included each one of the birds in turn and extracting the cluster structure of the remaining three-bird observations. For three individuals, the jackknifed results were not strikingly different from those produced by the full data set, aside from moderate reductions in significance due to decreased sample size. When interactions involving Pounamu, the youngest female, were removed from analysis, however, the resulting cluster structure was notably more coherent, forming a clear play cluster of three interconnected, significant linkages (among Bite, Foot Push, and Chin Over) and one related trend (Hop and Foot Push), in addition to a significant, unconnected association between Flap and Jump. The structure of Pounamu's social interactions appears to have deviated from that of the other birds, presumably reflecting her immature status, distorting the cluster pattern in the aggregate analysis. For species comparisons, we made use of only the more complex structure, leaving out Pounamu's interactions (Figure 1).

The structure of kakapo play is far simpler than that of either keas or kakas. Keas display two significantly associated clusters (Figure 


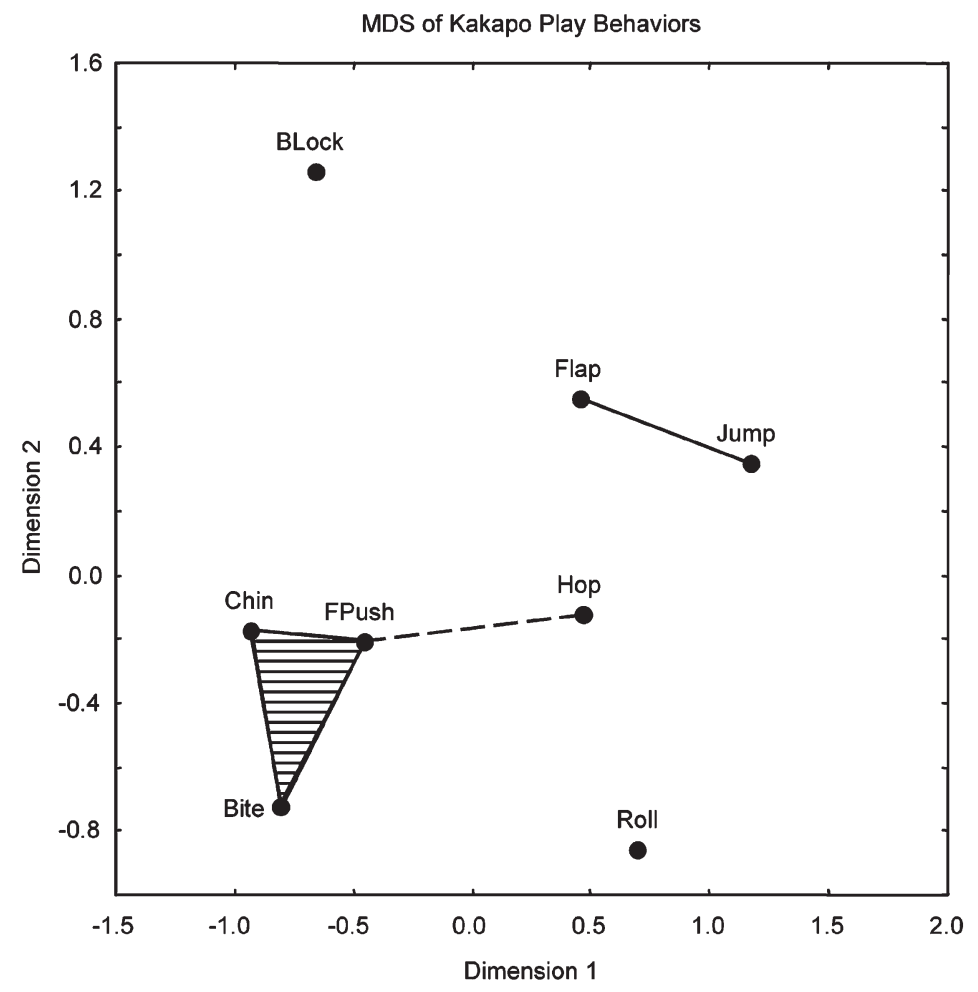

Figure 1. Cluster structure of kakapo action patterns, derived from multidimensional scaling of the hypergeometric similarity matrix. Pairs of behavioral events with similarity values $\geq 0.95$ were considered significant and are linked with solid lines; pairs with similarity values between 0.90 and 0.95 were considered trends and are linked with dashed lines. Note that there was one significantly associated cluster of play action patterns, consisting of Bite, Chin Over, and Foot Push, with an associated trend linking them to Hop. There was also an additional significant linkage between Jump and Flap.

2). The first, consisting of Hop, Head Cock, Wing Flap and Jump, appears to reflect the kea's typical "jump and flap" play interaction, initiated with a hopping approach and a head cock. The second cluster, consisting of Hop, Foot Push, Roll Over, and Bite, captures their more intense, rough-and-tumble play episodes, again initiated with a hopping approach, but in this case leading to biting and wrestling on the ground. The cluster analysis of kaka play shows three tightly interlinked groupings (Figure 3). One consists of Hop, Head Cock, Roll Over, and Jump, which are the initial constituents of a typical episode of play on the ground. Jump is also linked into a second cluster with Bite, Flap, and Foot-Push, representing a later stage in the interaction, 


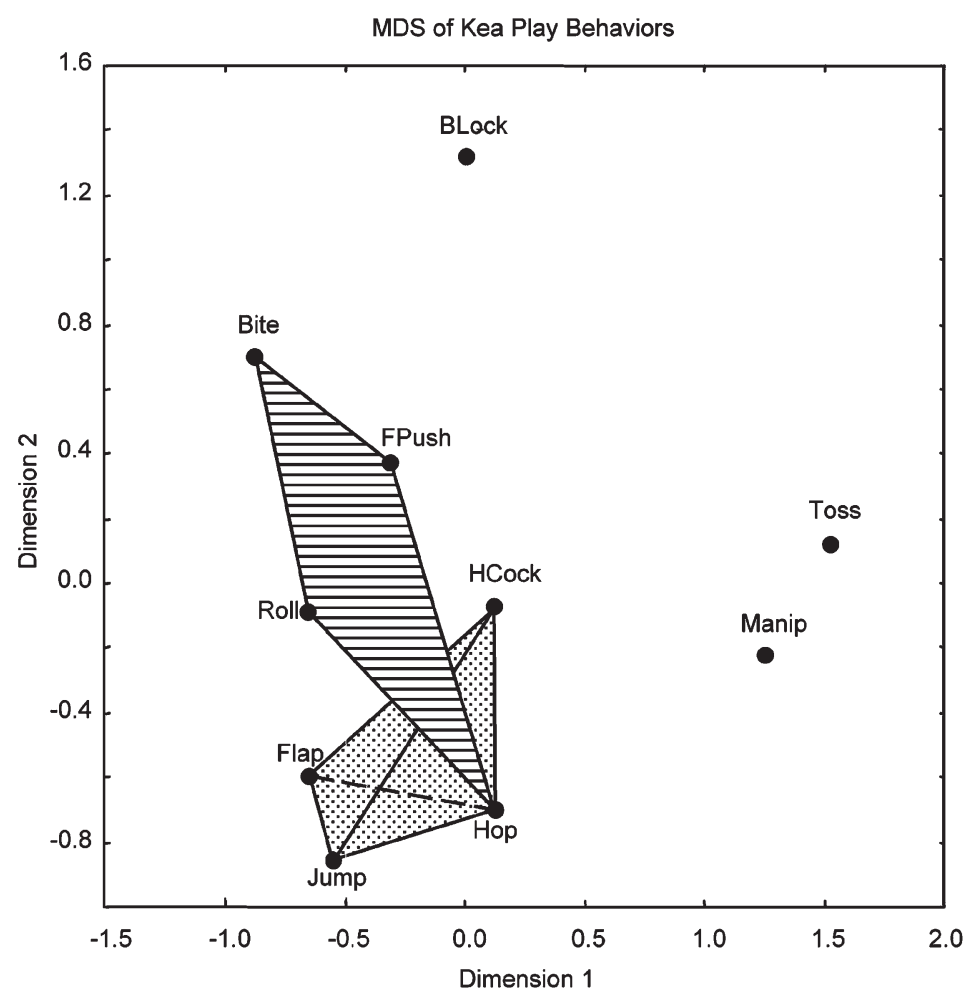

Figure 2. Cluster structure of kea action patterns, derived from multidimensional scaling of the hypergeometric similarity matrix. Pairs of behavioral events with similarity values $\geq 0.95$ were considered significant and are linked with solid lines; pairs with similarity values between 0.90 and 0.95 were considered trends and are linked with dashed lines. Note that there were two significantly associated clusters of play action patterns (indicated by shading within groupings), with Hop occurring in both of them.

in which one kaka stands on the partner's stomach on the ground, flapping its wings, pushing with its feet, and biting at the partner's feathers. The overlapping third cluster, consisting of Flap, Bite, FootPush, and Hang, derives from kaka play episodes in the trees.

\section{Discussion}

Comparisons of social play

Kakapo social play is strikingly different from that observed in either keas or kakas. The differences are evident in play composition, 


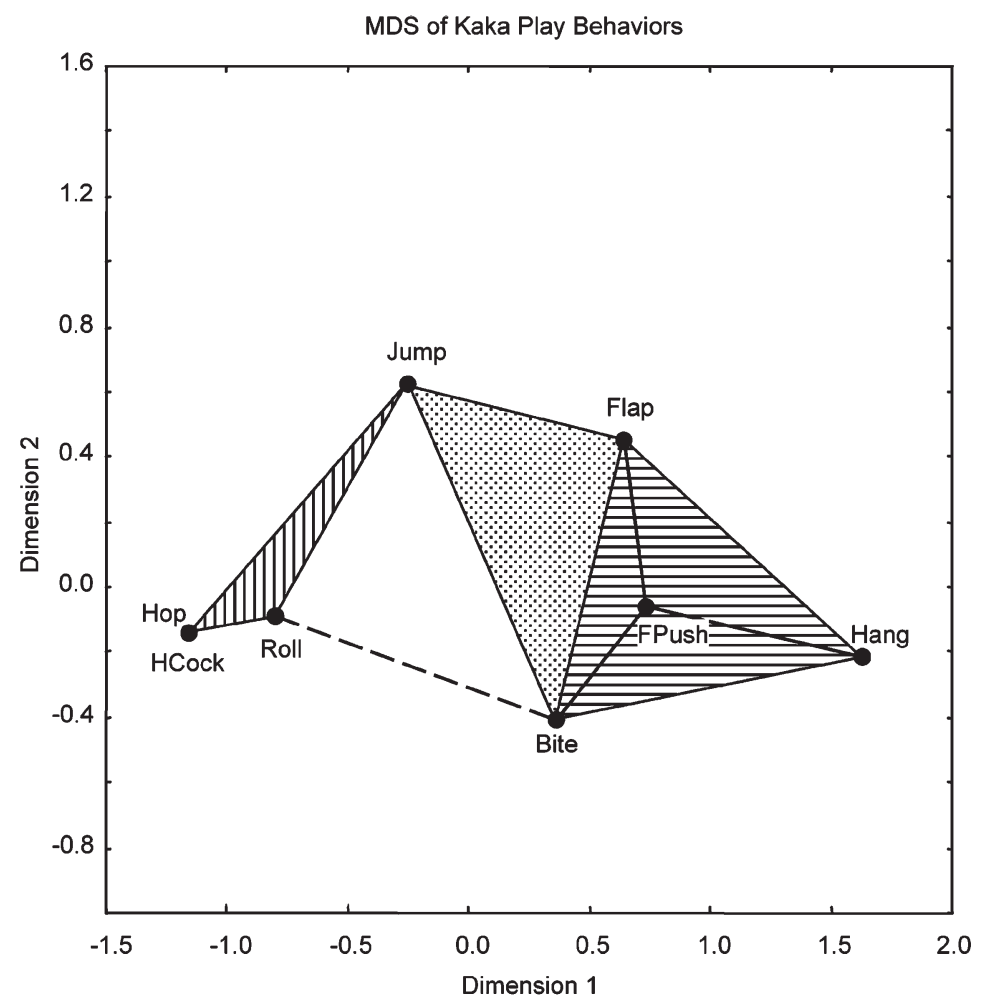

Figure 3. Cluster structure of kaka action patterns, derived from multidimensional scaling of the hypergeometric similarity matrix. Pairs of behavioral events with similarity values $\geq 0.95$ were considered significant and are linked with solid lines; pairs with similarity values between 0.90 and 0.95 were considered trends and are linked with dashed lines. Note that there were three significant clusters of play action patterns (indicated by shading) that were tightly interlinked. Jump, Flap, and Bite all occurred in more than one cluster.

intensity, duration, structure, and reciprocity. Of the ten play action patterns observed in the three species, only Bite and Bill Lock occurred in kakapo at frequencies comparable to those recorded in keas and kakas. Foot Push, Hop, Wing Flap, and Jump were all less frequent, and Head Cock and Toss were not shown in kakapos. Several other play action patterns observed in the Nestor parrots - Roll Over, Hang, and Manipulate - were observed in kakapos, but not in a social context. The most frequent behavior in kakapo play was Chin Over, which has not been recorded from either keas or kakas.

Kakapo play was lower in intensity than that of keas or kakas. The action patterns Foot Push, Bite, and Bill Lock were displayed much less vigorously and forcefully in kakapos, resembling something more 
like play nuzzles than the mock combat typical of Nestor play. Kakapo play episodes were significantly shorter in duration than those of either keas or kakas. Social play in kakapos also showed a less coherent behavioral structure than did that of either of the other species. There was only one significant cluster (Chin Over, Bite, and Foot Push) that appeared to be central to play activity; no other action patterns grouped with them above the 0.95 threshold. In contrast, keas and kakas showed several tightly interlinked and readily interpreted clusters of play actions.

Finally, kakapo play differed from that of the Nestor parrots in showing very limited reciprocity. Recipients of initial play actions were commonly unresponsive to the approach of the other bird, or they simply moved away. There was occasionally reciprocal biting within a single play bout, but we saw little evidence of attempts to reinitiate play once it had been terminated. In contrast, play in both keas and kakas is highly reciprocal and interactive. The recipient of play invitations responds by actively approaching and engaging in similar behavior patterns; attempts by one of the partners to unilaterally disengage from the interaction are commonly resisted by the other; and partners often appear to take alternating roles in successive play episodes. Because kakapos show only low-intensity play fighting, and do not display play chasing, play invitations, or social object play, they would be classified as engaging in simple, rather than complex, play (Diamond \& Bond, 2003).

In general, keas and kakas are far more similar to one another in their social play than either species is to kakapos. Keas and kakas do show characteristic, but less extreme, species differences in social play, however. Both Nestor parrots engage in complex and persistent social play, with keas exhibiting a more variable pattern and kakas showing a more stereotyped one (Diamond \& Bond, 2004). Most play action patterns appear to be homologous in keas and kakas, and though there are significant differences in the form of specific play behaviors, such as kicking or biting, these could be attributed to morphological differences. The most striking species difference was exhibited in social object play, which is pervasive among keas, but which was not observed in kakas. In structure, social play in kakas is briefer, more predictable, and less diverse than that shown by keas. Play initiation behaviors are relatively more frequent in kakas and more tightly intercorrelated in their occurrence. Based on the criteria of Diamond \& Bond (2003), however, both keas and kakas exhibit complex social play. 


\section{Implications of rarity and captivity}

The extreme rarity of kakapos, combined with their secretiveness and solitary, nocturnal habits, severely limits the opportunities for observing social play in the field. We acknowledge that the circumstances of these captive observations differ from those made of kea and kaka interactions in the wild. The most central concern, thus, is to assess the degree to which the present conditions of kakapo management may have influenced the occurrence of social play in captive individuals.

According to Maori tradition (Buller in Turbott, 1967), kakapos formerly aggregated in large numbers during the winter months, when their vocalizations were audible for miles away. Buller notes that the species is not gregarious at other seasons, and asserts that at these times, the birds are mainly found in family groups of two or three. Climo \& Balance (1997) noted that female kakapos have been found roosting next to the nest of a brooding female and that young males were found near older ones during the breeding season. The significance of such anecdotal accounts in determining the degree of sociality of kakapos is difficult to assess.

Farrimond (2003) found that adult females and their young of the year remain in each other's home ranges for a substantial period after the young have left the nest, presenting at least the opportunity for social interactions among family members. There is some suggestion that kakapos that fledge from single-offspring nests differ in their juvenile behavior patterns from those that fledge with a sibling. Farrimond (2003) noted that kakapos from single-chick broods fledged much earlier than those that matured in the company of a sibling. This did not reflect nutritional differences, as there was no effect of brood size on growth rate. Farrimond speculated that the difference in age of fledging may have been related to the absence of a social partner.

Higher levels of social interaction among chicks from larger broods were also seen in the current study. The two sibling females participated in nearly twice as many social interactions as the solitary-raised male and female. This was not, however, a consequence of favoring interactions with one another, because the relative frequencies of the six possible dyads were consistent with random association. The inference seems to be that the sibling females were simply more interactive than the other two birds, possibly reflecting differences in the social stimulation they received as nestlings. 
There is no evidence that hand rearing, even in isolation from other fledglings, affects the birds' subsequent success at foraging and social interaction. Hand-reared kakapos appear to develop normal social relationships with other birds in the field. Although hand-reared males have not yet established bowl systems linked to those of wild males, one hand-reared male has established a bowl on his own, and others have investigated booming males and produced minor booming themselves (Eason, personal communication). The only sexually mature hand-raised female kakapo has now mated and hatched a chick of her own in the wild (Eason \& Morehouse, 2006).

Captivity does not, of itself, preclude normal play behavior. Social play in keas was first described from captive birds, and the behavior did not differ substantially from play observed in the wild (Keller, 1975; Diamond \& Bond, 1999). Play has not been recorded in captive kakas, but it has been observed in many other species of captive parrots (e.g., hyacinth macaw Anodorhynchus hyacinthus: Hick, 1962; green-winged macaw Ara chloroptera: Deckert \& Deckert, 1982; monk parakeet Myiopsitta monachus: Shepherd, 1968; budgerigar Melopsittacus undulatus: Engesser, 1977; and spectacled parrotlet Forpus conspicillatus: Garnetzke-Stollmann \& Franck, 1991).

Confining four fledgling kakapos within a restricted area may produce a "behavioral sink" (Calhoun, 1962), in which the frequency of social encounters is higher than would normally occur in the wild. It is worth noting, however, that observations of social play in keas and kakas in the wild were also made under conditions in which the birds were highly aggregated. Play may be more readily elicited - or more readily observed-in such aggregations, suggesting that the differences in social play among the three species are unlikely to have been a consequence of differences in observational conditions. Similarly, play in captive mammals has been shown to increase in frequency over that observed in the wild, but the form of the play remains the same (Pasztor et al., 2001).

\section{Play and life history}

In this study, we have used kakapos as a test of a predictive model of social play, comparing keas and kakas to a closely related species that provides a stronger contrast in life history and social organization (Diamond \& Bond, 2003). Previous studies suggest that both keas and kakas aggregate socially in medium to large groups of both adults and juveniles (Diamond \& Bond, 1999). There is little evidence that 
kakapos engage in much social behavior outside of breeding interactions and female care of nestlings (Higgins, 1999; Farrimond, 2003).

There are also substantial differences among these three species of parrot in the course of social development of the young. Kakas fledge about ten weeks after hatching, and they are fed by their parents for another 5-6 weeks. They remain with adults to about six months of age, when they generally disperse from the natal area, but they continue to associate with other kakas in feeding flocks (Moorhouse \& Greene, 1995). Female kakas are able to breed as early as one year of age (Moorhouse, personal communication). Keas take longer to fledge, though, like kakas, they are fed by their parents for another 5 to 6 weeks (Jackson, 1963). Young keas continue to associate with adults for up to two years, during which time they form loose juvenile flocks, where they scrounge food that adults have located (Diamond \& Bond, 1999; Elliott \& Kemp, 1999). Keas do not begin to breed until they are three to four years of age (Higgins, 1999).

Kakapos mature more slowly than either of the Nestor parrots (56 years for males and 9 years for females; Merton et al., 1984). Information on kakapo behavioral development in the wild is limited, and much of what is known comes from radio tracking rather than direct observations. Farrimond's (2003) data suggest that kakapos fledge at about the same time as the Nestor parrots, at around ten weeks, but then their developmental patterns diverge. For several months after fledging, juvenile kakapos remain on their mother's home range or else return to within $150 \mathrm{~m}$ of her to roost during the day. How much of this failure to disperse involves post-fledging socialization is difficult to assess. Young kakapos reach their maximum weight at about 30 weeks of age, suggesting that the female may continue to feed them, at least occasionally, for several months after fledging. It is, however, unlikely that adults and young interact socially outside of the breeding season; the amount of overlap between home ranges in kakapos is generally no larger than one would expect by chance, even for related individuals (Farrimond, 2003). Apparently, they are not generally seeking one another out for social purposes.

Surveys of the play literature have demonstrated a general relationship between the complexity of social play and the age of first reproduction (Pellis \& Iwaniuk, 2000; Diamond \& Bond, 2003). Diamond and Bond (2003) found that parrots and corvids that exhibited simple social play showed an age of maturity that was in line with what would be expected of an average bird of their body size; 
those that demonstrated more complex social play had a significantly greater age of maturity. The current study, however, suggests that age of first reproduction, by itself, is unlikely to be the critical determinant of play complexity. In keas and kakas, play complexity seems less a consequence of delayed reproduction than a reflection of persisting associations between post-fledging young and adults. Kakapos have a higher age of first reproduction than either keas or kakas, but they appear to lack well developed social interactions between post-fledging young and adults, and their social play is briefer, less reciprocal, and considerably less complex in structure than that of the Nestor parrots.

Social play in parrots thus appears to be most readily predicted from their patterns of social development, emerging within a constellation of affiliative behaviors associated with independent young that remain in the vicinity of adult groups. It is even possible that play has evolved as a consequence of selection for sociality among such independent young and adults. After fledging, juvenile keas commonly follow adults around, displaying distinctive solicitation behaviors to obtain access to food resources. Juvenile keas thus derive benefits from remaining in the vicinity of adult groups (Diamond \& Bond, 1991), and this may also be true, to a lesser degree, in kakas. Play can be seen as one of several social mechanisms that stabilize such group affiliations. If play serves as a mechanism for maintaining cohesion in multiage flocks, it would not be expected to occur to the same extent in species in which the young disperse soon after fledging. The relatively limited social system of post-fledging kakapos thus predicts a lower incidence and complexity of social play, and this is precisely what we observed.

These results provide insight into the evolution of play in one group of New Zealand parrots. Additional comparisons will clearly be required to support the inferred relationship between life history variables and avian social play. The primary conclusion from this study, however, is that there is a need for further research on the social behavior of juvenile birds, a relatively unexamined stage of avian life history. Most studies of social behavior in birds have focused primarily on the behavior of adults or nestlings, without giving comparable weight to the dynamics of young birds as they emerge into adult society. The comparative study of play highlights the events involved in this transitional period and argues that their study will enhance our understanding of the ontogeny and evolution of sociality in birds. 


\section{Acknowledgments}

This work was supported in part by the University of Nebraska State Museum, the New Zealand Department of Conservation, and Grant MH069893 from the National Institutes of Mental Health and was assisted by the staff and volunteers of the Department of Conservation's kakapo recovery program. We are particularly grateful to R. Moorhouse and G. Elliott for making this study possible, to M. Farrimond for giving us access to her research findings, to T. Suhr for assisting in data conversion, and to two anonymous reviewers for their helpful and constructive comments. Finally, we acknowledge the generous financial support provided by Comalco New Zealand, a principal sponsor of the kakapo recovery program.

\section{References}

Arabie, P. \& Carroll, J. D. (1980). MAPCLUS: A mathematical programming approach to fitting the ADCLUS model. Psychometrika 45: 211-235.

Arabie, P. \& Carroll, J. D. (1989). Conceptions of overlap in social structure. In: Research methods in social network analysis (Freeman, L. C., White, D. R. \& Romney, A. K., eds). George Mason University Press, Fairfax, VA, pp. 367-392.

Arabie, P., Carroll, J. D., DeSarbo, W. \& Wind, J. (1981). Overlapping clustering: A new method for product positioning. J. Marketing Res. 18: 310-317.

Barber, N. (1991). Play and energy regulation in mammals. Q. Rev. Biol. 66: 129-147.

Bekoff, M. (1974). Social play and play-soliciting by infant canids. Am. Zool. 14: 323- 340.

Bekoff, M. (1976). Animal play: problems and perspectives. In: Perspectives in ethology, Vol. 2 (Bateson, P. P. G. \& Kolpfer, P. H., eds). Plenum, New York, pp. 165-188.

Bekoff, M. (1984). Social play behavior. Bioscience 34: 228-233.

Bekoff, M. \& Allen, C. (1998). Intentional communication and social play: how and why animals negotiate and agree to play. In: Animal play: evolutionary, comparative and ecological perspectives (Bekoff, M. \& Byers, J. A., eds). Cambridge University Press, Cambridge, pp. 97-114.

Bekoff, M. \& Byers, J. A. (1981). A critical reanalysis of the ontogeny and phylogeny of mammalian social and locomotor play: an ethological hornet's nest. In: Behavioural development: The Bielefield interdisciplinary conference (Immelmann, K., Barlow, G., Petrinovich, L. \& Main, M., eds). Cambridge University Press, New York, pp. 296-337.

Bond, A. B., Kamil, A. C. \& Balda, R. P. (2003). Social complexity and transitive inference in corvids. Anim. Behav. 65: 479-487.

Burghardt, G. M. (2005). The genesis of animal play, testing the limits. Cambridge, MIT Press.

Butler, D. (1989). Quest for the kakapo. Heinemann Reed, Auckland.

Calhoun, J. B. (1962). A behavioral sink. In: Roots of behavior (Bliss, E. L., ed. ). Harper \& Row, New York, pp. 295-315.

Cassini, M. H. \& Vila, B. L. (1990). Cluster analysis of group types in southern right whale, Eubalena australis. Mar. Mammal. Sci. 6: 17-24. 
Climo, G. \& Balance, A. (1997). Hoki: the story of a kakapo. Godwit, Auckland.

Cockrem, J. F. (2002). Reproductive biology and conservation of the endangered kakapo (Strigops habroptilus) in New Zealand. Avian and Poultry Biol. Rev. 13: 139-144.

Collar, N. J. (1997). Family Psittacidae (Parrots). In: Handbook of birds of the world, Vol. 4: Sandgrouse to Cuckoos (del Hoyo, J., Elliott, A. \& Sargatal, J., eds). Lynx Edicions, Barcelona, pp. 280-477.

Deckert, G. \& Deckert, K. (1982). Spielverhalten und Komfortbewegungen beim Grünflügelara (Ara chloroptera G. R. Gray). Bonn. Zool. Beitr. 33: 269-281.

Diamond, J. \& Bond, A. (1991). Social behaviour and the ontogeny of foraging in the kea (Nestor notabilis). Ethology 88: 128-144.

Diamond, J. \& Bond, A. (1999). Kea, bird of paradox, the evolution and behavior of a New Zealand parrot. University of California Press, Berkeley, CA.

Diamond, J. \& Bond, A. (2003). A comparative analysis of social play in birds. Behaviour 140: 1091-1115.

Diamond, J. \& Bond, A. (2004). Social play in the kaka (Nestor meridionalis) with comparisons to kea (Nestor notabilis). Behaviour 141: 777-798.

Eason, D. K., Elliott, G. P., Merton, D. V., Jansen, P. W., Harper, G. A. \& Moorhouse, R. J. (2006). Breeding biology of kakapo (Strigops habroptilus) on offshore island sanctuaries, 1990-2002. Notornis 53: 27-36.

Eason, D. K. \& Moorhouse, R. J. (2006). Hand-rearing kakapo (Strigops habroptilus), 1997- 2005. Notornis 53: 116-125.

Elliott, G. \& Kemp, J. (1999). Conservation ecology of kea (Nestor notabilis). WWFNZ Final report. World Wildlife Fund for Nature, New Zealand.

Elliott, G. P., Merton, D. V. \& Jansen, P. W. (2001). Intensive management of a critically endangered species: the kakapo. Biol. Cons. 99: 121-133.

Engesser, U. (1977). Sozialisation junger Wellensittiche (Melopsittacus undulatus). Z. Tierpsychol. 43: 68-105.

Fagen, R. (1981). Animal play behaviour. Oxford University Press, New York.

Farrimond, M. A. (2003). Fledging and dispersal of Kakapo, Strigops habroptilus. MS thesis, Environmental and Marine Science, University of Auckland.

Felsenstein, J. (1985). Phylogenies and the comparative method. Am. Nat. 125: 1-15.

Forshaw, J. M. (2006). Parrots of the world. Princeton University Press, Princeton, NJ.

Garnetzke-Stollmann, K. \& Franck, D. (1991). Socialization tactics of the spectacled parrotlet (Forpus conspicillatus). Behaviour 119: 1-29.

Gray, H. L. \& Schucany, W. R. (1972). The generalized jackknife statistic. Marcel Dekker, New York, NY.

Harvey, P. H. \& Pagel, M. D. (1991). The comparative method in evolutionary biology. Oxford University Press, New York.

Heinrich, B. \& Smolker, R. (1998). Play in common ravens (Corvus corax). In: Animal play: Evolutionary, comparative and ecological perspectives (Bekoff, M. \& Byers, J. A., eds). Cambridge University Press, Cambridge, pp. 27-44.

Hick, U. (1962). Beobachtungen über das Spielverhalten unseres Hyazinth Ara (Anodorhynchus hyacinthus). Freunde d. Kölner Zoo 5: 8-9.

Higgins, P. J. (1999). Handbook of Australian, New Zealand and Antarctic birds. 
Vol. 4. Parrots to dollarbird. Oxford U. Press, Melbourne, Auckland.

Iwaniuk, A. N., Nelson, J. E., James, H. F. \& Olson, S. L. (2004). A comparative test of the correlated evolution of flightlessness and relative brain size in birds. J. Zool. (London) 263: 317-327.

Jackson, J. R. (1963). The nesting of keas. Notornis 10: 319-326.

Juniper, T. \& Parr, M. (1998). Parrots, A guide to parrots of the world. Yale University Press, New Haven.

Kamil, A. C. (1988). A synthetic approach to the study of animal intelligence. In: Comparative perspectives in modern psychology: Nebraska symposium on motivation (Leger, D., ed. ), Vol. 35. University of Nebraska Press, Lincoln, NE, pp. 230-257.

Keller, R. (1975). Das Spielverhalten der Keas (Nestor notabilis Gould) des Zürcher Zoos. Z. Tierpsychol. 38: 393-408.

de Kloet, R. S. \& de Kloet, S. R. (2005). The evolution of the spindlin gene in birds: Sequence analysis of an intron of the spindlin $\mathrm{W}$ and $\mathrm{Z}$ gene reveals four major divisions of the Psittaciformes. Mol. Phylogenet. Evol. 36: 706-721.

Kraemer, H. C. (1979). One-zero sampling in the study of primate behaviour. Primates 20: 237-244.

Li, X. \& Dubes, R. (1984). Selection of significant dichotomous features. Proc. 7th Int. Conf. Pattern Recog. IEEE. New York, pp. 260-263.

Li, X. \& Dubes, R. (1989). A probabilistic measure of similarity for binary data in pattern recognition. Pattern. Recog. 22: 397-409.

Lorenz, K. Z. (1956). Plays and vacuum activities. L'Instinct dans le comportment des animax et de l'homme. Fondation Singer-Polignac, Masson et Cie, Paris, pp. 633-646.

Luo, X. (1989). A practical sieve algorithm for finding prime numbers. Comm. ACM 32: 344-346.

Merton, D. V.,Morris, R. B. \& Atkinson, I. A. E. (1984). Lek behaviour in a parrot: the Kakapo (Strigops habroptilus) in New Zealand. Ibis 126: 277-283.

Moorhouse, R. J. \& Greene, T. C. (1995). Identification of fledgling and juvenile kaka (Nestor meridionalis). Notornis 42: 187-196.

Morgan, B. J. T., Simpson, M. J. A., Hanby, J. P. \& Hall-Craggs, J. (1976). Visualizing interaction and sequential data in animal behaviour: theory and application of cluster-analysis methods. Behaviour 56: 1-43.

Ortega, J. C. \& Bekoff, M. (1987). Avian play: Comparative evolutionary and developmental trends. Auk 104: 338-341.

Pasztor, T. J., Smith, L. K., MacDonald, N. L., Michener, G. R. \& Pellis, S. M. (2001). Sexual and aggressive play fighting of sibling Richardson's ground squirrels. Aggr. Behav. 27: 323-337.

Paz-y-Miño, C. G., Bond, A. B., Kamil, A. C. \& Balda, R. P. (2004). Pinyon jays use transitive inference to predict social dominance. Nature 430: 778-781.

Pellis, S. M. (1981a). Exploration and play in the behavioural development of the Australian magpie Gymnorhina tibicen. Bird Behav. 3: 37-49.

Pellis, S. M. (1981b). Description of social play by the Australian magpie Gymnorhina tibicen based on Eshkol-Wachman notation. Bird Behav. 3: 61-79.

Pellis, S. M. (1982). Development of head and foot coordination in the Australian magpie Gymnorhina tibicen, and the function of play. Bird Behav. 4: 57-62. 
Pellis, S. M. \& Iwaniuk, A. N. (2000). Comparative analysis of the roles of postnatal development in the expression of play fighting in juveniles and adults. Dev. Psychobiol. 36: 136-147.

Potts, K. J. (1969). Ethological studies of the kea (Nestor notabilis) in captivity: Nonreproductive behaviour. BS thesis. Victoria University, Wellington, New Zealand.

Power, T. G. (2000). Play and exploration in children and animals. Lawrence Erlbaum Assoc. Pubs., Mahwah, NJ.

Powlesland, R. G., Lloyd, B. D., Best, H. A. \& Meron, D. V. (1992). Breeding biology of the Kakapo Strigops habroptilus on Stewart Island. Ibis 134: 361-373.

Pozis-Francois, O., Zahavi, A. \& Zahavi, A. (2004). Social play in Arabian babblers. Behaviour 141: 425-450.

Rhine, R. J. \& Linville, A. K. (1980). Properties of one-zero scores in observational studies of primate social behaviour: the effect of assumptions on empirical analyses. Primates 21: 111-122.

Sainsbury, J. P., Macavoy, E. S. \& Chambers, G. K. (2004). Characterization of microsatellite loci in the kaka, Nestor meridionalis. Mol. Ecol. Notes. 4: 623-625.

Shepard, R. N. \& Arabie, P. (1979). Additive clustering: Representation of similarities as combinations of discrete overlapping properties. Psych. Rev. 86: 87-123.

Shepherd, P. (1968). Some notes on the breeding of the Quaker parakeet (Myiopsitta monachus). Avicult. Mag. 74: 210-211.

Shettleworth, S. J. (1998). Cognition, evolution, and behaviour. Oxford U. Press, Oxford.

Simmons, R. E. \& Mendelsohn, J. M. (1993). A critical review of cartwheeling flights of raptors. Ostrich 64: 13-24.

Singh, R. (1989). Ontogeny of aggressive and submissive behaviour in free living rhesus monkeys (Macaca mulatta). Proc. Indian Acad. Sci. (Anim. Sci. ) 98: 139-148.

Skutch, A. F. (1987). Helpers at birds' nests. University of Iowa Press, Iowa City, IA.

Spinka, M., Newberry, R. C. \& Bekoff, M. (2001). Mammalian play: training for the unexpected. Quart. Rev. Biol. 76: 141-168.

Turbott, E. G. (1967). Buller's birds of New Zealand. East-West Center Press, Honolulu.

Tyler, S. (1979). Time-sampling: a matter of convention. Anim. Behav. 27: 801-810.

Wilmore, S. B. (1977). Crows, jays, ravens and their relatives. David \& Charles, Newton Abbot, England.

$\mathrm{Wu}, \mathrm{T}$. (1993). An accurate computation of the hypergeometric distribution function. ACM Trans. Math. Software 19: 33-43.

Zinner, D., Hindahl, J. \& Schwibbe, M. (1997). Effects of temporal sampling patterns of all-occurrence recording in behavioural studies: many short sampling periods are better than a few long ones. Ethology 10: 236-246. 